\title{
A RECUPERAÇÃO DA COERÊNCIA EM UM MANUAL DE INSTRUÇÕES
}

Cristina Zambra*

\begin{abstract}
RESUMO: Pretende-se, com este trabalho, colher evidências que permitam uma compreensão sobre o processo de leitura de manuais de instruções. Para isso, tomam-se, como aporte teórico, as meta-regras de coerência de Charolles (1988). Através da análise da meta-regra de repetição, realizou-se o estudo de duas páginas de um manual de instruções, contemplando questões referentes à recepção desse tipo de texto (especializado), mediante a relação que se estabelece entre leitor e texto, via coerência global.
\end{abstract}

PALAVRAS-CHAVE: Leitura - Meta-Regras - Coerência

RESUMEN: Con ese trabajo, se pretende recoger evidencias que permitan una comprensión sobre el proceso de lectura de manuales de instrucciones. Para éso, se usa, como aporte teórico, las meta-reglas de coherencia (CHAROLLES, 1988). A través del análisis de la meta-regla de repetición, se realizó el estudio de dos páginas de un manual de instrucciones, contemplando cuestiones referentes a la recepción de ese tipo de texto (especializado), mediante la relación entre lector y texto, vía coherencia global.

PALABRAS-CLAVE: Lectura - Meta-Reglas - Coherencia

\section{INTRODUÇÃO}

Quando nos propomos a comunicar algo a alguém, através da escrita, esperamos que nosso interlocutor tenha um mínimo de conhecimento do que seja um texto, acionando para tanto a chamada competência textual ${ }^{1}$ que nos faz reconhecer o mesmo coerentemente, resultado da interação entre leitor e texto, pela atuação conjunta de uma série de fatores de ordem cognitiva, informacional, situacional, sociocultural e interacional. Pensar essa atuação conjunta de elementos significativos reportar-nos-á, neste trabalho, aos estudos da Lingüística Textual (doravante LT), teoria que nos leva a entender as questões relacionadas à produção e recepção do texto escrito. Assim, a compreensão ou não de um determinado gênero textual, segundo a LT, dependerá muito de fatores internos e externos ao texto, e claro, também de cada leitor. Dessa forma, para que as frases não sejam apenas palavras uma ao lado da outra, sem sentido algum, de acordo com Charolles (1988), é possível

\footnotetext{
Especialista em Estudos Linguísticos do Texto - Instituto de Letras - UFRGS. E-mail: cristinazambra@yahoo.com.br

${ }^{1}$ Através dessa competência, somos capazes de reconhecer os diversos gêneros textuais, averiguando se em um texto predominam seqüências de caráter narrativo, descritivo, argumentativo (cf. Koch, 1997).
} 
descrever regras (critérios) de boa formação de textos, que se constituem em um, assim definido pelo autor, bloco de interpretações ${ }^{2}$.

Com o intuito de reconhecer os processos de compreensão de leitura por que passa um texto, nos remetemos à construção de sentido de um texto descritivo e objetivo, a fim de responder à seguinte pergunta: como o leitor recupera a coerência em um manual de instruções? Partimos das quatro meta-regras propostas por Charolles (1988), acreditando que a coerência de um dado texto não é imediatamente percebida pelo leitor, é, sim, processada aos poucos, levando em conta conhecimento de mundo e conhecimento lingüístico. Daí a nossa escolha pelas meta-regras de coerência, as quais nos servem de parâmetros durante a interpretação textual, ajudando, dessa maneira, a estudar o que determina o sentido em um texto especializado. Assim sendo, o presente artigo pretende analisar e descrever fatores de compreensão de leitura instaurados em um manual de instruções que prescreve etapas do processo de instalação e funcionamento de um aparelho de DVD.

Do exposto, o trabalho justifica-se pela importância e influência que os textos especializados (ou técnicos) têm na nossa vida cotidiana, ou melhor, na nossa vida de leitores. Percebemos isso quando adquirimos, por exemplo, um eletrodoméstico. Para instalá-lo e fazê-lo funcionar é preciso que tenhamos à mão seu complicado manual de instruções, no que se refere ao léxico, estrutura (a disposição dos elementos dentro do texto) e termos técnicos, porém de importante utilidade como guia de funcionamento do aparelho.

Nós, os consumidores, não sabemos, por exemplo, definir muitos dos vocábulos específicos que descrevem um aparelho eletrônico, o que sem dúvida prejudica a construção do sentido do texto. Propomo-nos, então, a refletir e discutir a importância de trabalhar esse gênero textual, de integrar nosso leitor nas discussões e de focalizar a análise na coerência global (CHAROLLES, 1988). Para isso, tratamos de, em um primeiro momento, discorrer sobre o texto especializado e sua compreensão de leitura; logo depois, descrever o corpus bem como os métodos empregados; em seguida, abrir um espaço para a análise dos resultados obtidos; e, por último, apresentar as considerações finais sobre o estudo realizado.

\section{O TEXTO ESPECIALIZADO E A COMPREENSÃO DE LEITURA}

Uma vez delimitado nosso objeto de estudo - o texto - é preciso destacar que várias são as teorias que o definem. Assim, tanto como unidade lingüística que comunica (elementos sintáticos e lexicais que, textualmente, fazem de um texto um todo de sentido) quanto unidade de linguagem em uso (a situação de interação como forma de construção do sentido), o texto se mostra verdadeiro, principalmente, para quem o produz, não tendo,

\footnotetext{
${ }^{2}$ Em uma situação comunicativa, em que se verificam papéis sociais de destinatários diferentes uns dos outros, conseqüentemente a interpretação não será única e nem sempre a mesma, ela vai depender muito de fatores lingüísticos e de cada destinatário. Nesse sentido, a interpretação pode contribuir fortemente para a construção de um ou de mais de um sentido global para o texto, formando dessa maneira, um conjunto de interpretações, fazendo com que um texto se torne coerente para quem o lê (cf. KOCH; TRAVAGLIA, 1989).
} 
muitas vezes, a mesma veracidade para quem o lê, pois, a esse último, a relação co-texto e con-texto $^{3}$ pode não ser entendida satisfatoriamente na interação leitor/texto e conseqüentemente no mundo que os cerca. Em outras palavras, o que se percebe é a não compreensão do que se está lendo, dificuldade essa que pode aparecer porque o leitor não fez a relação entre os elementos constitutivos do próprio texto, ou seja, não estabeleceu a relação existente das palavras com as orações, para que se construísse, dessa maneira, o sentido global.

Em se tratando do texto técnico, no momento de sua produção, quem escreve deve cuidar para que a intenção de produzi-lo tenha encaminhamento claro e bem definido, para que o leitor identifique nos elementos lingüísticos tal intenção. Koch (op.cit) afirma que a construção de sentido vai além do que está posto no texto, considerando sua relação com outros textos. Nesse sentido, é necessário desvendar o enigma da compreensão através de uma leitura comum ao produtor e ao leitor (a intertextualidade entre o elaborador e o recebedor do texto), mesmo não havendo, textualmente, a possibilidade de interação entre eles, assim, a intenção daquele que produz o texto será aceita por aquele que o recebe.

Para Kleiman (1989, p. 67), produtor e leitor, cada um, têm suas responsabilidades, seja produzindo, seja lendo. O leitor tem a tarefa de descobrir os macetes e intenções propostas pelo produtor do texto, relendo quantas vezes for necessária cada parte, cada frase ou parágrafo. A autora argumenta, ainda, que a compreensão de leitura somente se estabelece com o processamento lógico-cognitivo, extravasado pelo leitor que se vê em condições de mentalizar pistas a partir do que leu, acionando, para tal tarefa, conhecimentos de mundo, textual e lingüístico. O leitor utiliza, para a construção do sentido, o que já sabe, o que nos leva a afirmar que, sem o acionamento do conhecimento prévio, mediante vivência desse leitor como indivíduo atuante lingüística e socialmente, não há compreensão. Vejamos o que a autora diz:

\begin{abstract}
A monitoração simultânea da compreensão do leitor não é possível na interação à distância, e daí na incompreensão do texto escrito ser um fenômeno freqüente, e daí também a insistência na responsabilidade maior de autor e leitor, responsabilidade esta que, para o caso do leitor, consiste em releituras, análise de palavras e frases, inferências, ativação de conhecimentos, e, para o autor, consiste em mapear claramente as pistas que permitam uma reconstrução do significado e da intenção comunicativa. (KLEIMAN, 1989, p. 67)
\end{abstract}

Para que possamos desenvolver um estudo profícuo acerca da relação leitor/texto, adotaremos as meta-regras de coerência propostas por Charolles (1988), as quais estabelecem um acordo de interesses lingüísticos e semânticos entre o produtor e o leitor, mediante uma dada situação. Entendemos que o texto Introdução aos Problemas da Coerência dos Textos, de autoria de Charolles, é o que melhor atenderá aos objetivos da nossa investigação, bem como ao recorte feito: a coerência global.

Em relação à textualidade, Charolles (1988, p. 40) afirma ser o texto constituído pelo sentido que cada leitor constrói e não por um conjunto de frases as quais nada têm a dizer. Isso nos leva a deduzir que, para o autor, a coerência global, em consonância com a

\footnotetext{
${ }^{3}$ Termos usados para designar os aspectos gramaticais e não-gramaticais (coesão e coerência) para um e questões da produção do texto e de sua recepção (situação comunicativa) para outro (cf. KOCH, 1997, p. 23).
} 
coerência local, faz de um texto um todo de sentido, capaz de dizer muitas coisas. A coerência global ou macroestrutural, de acordo com Charolles (1988, p.52), estabelece relações entre frases e seqüências no enunciado, garantindo o sentido; a coerência local ou microestrutural incide nas relações que se estabelecem entre as seqüências consecutivas, entre as palavras. Nesse sentido, acredita que a coerência (global e local) parte do princípio da interpretabilidade, em que todos os textos seriam em princípio aceitáveis, o texto, porém, será incoerente se, e somente se, o seu produtor não souber adequá-lo à situação de comunicação, a objetivos definidos e a diferentes tipos de destinatários, propósitos esses que, se não forem contemplados, acarretarão dificuldades de compreensão para o leitor. Dessa forma, em relação ao manual de instruções, acreditamos que a coerência global nos ajudará a construir o sentido do texto, mediante análise da repetição. A compreensão da leitura é dificultada na recepção desse gênero de texto, por isso, à luz da coerência global, pretendemos descrever e explicar a relação existente entre o texto especializado e seu leitor.

Adotar as meta-regras de coerência para que o texto seja reconhecido como bem formado, num dado contexto situacional, é tentar garantir que o mesmo seja aceito por quem o lê, mesmo que à primeira vista pareça um aglomerado de palavras, totalmente incoerente. Porém, é importante destacar que o estudo da coerência não precisa necessariamente partir dos propósitos dessas meta-regras, pois dependerá do tipo de texto, muitas vezes elas não são suficientes para explicitar as marcas lingüísticas as quais são indícios de construção de sentido no texto. Em se tratando do manual de instruções, acreditamos que esses critérios de boa formação textual possibilitem, a quem está lendo, organizar as idéias contidas no texto de tal maneira que se possa compreender, na sua totalidade, os objetivos e anseios desejados.

\section{A repetição na construção de sentido do texto especializado}

Optamos por analisar apenas a repetição, que, de acordo com Charolles, diz que o texto, para ser coerente, no seu desenvolvimento linear, deve ter elementos de recorrência estrita para não se perder o fio da meada e dar seqüência ao que foi dito através de pronomes demonstrativos, repetições, substituições lexicais, definitivações. Tendo em vista nossas expectativas quanto ao desenvolvimento do trabalho e quanto ao material utilizado e estudado, acreditamos que a repetição é fundamental na recepção do texto pelo leitor, pois dá seqüência aos conceitos, reorganizando-os e garantindo a continuação de uma idéia no detalhamento de passos para instalação de um aparelho eletrônico.

Repetir, no caso deste estudo, significa, principalmente, retomar o que foi dito para que haja uma progressão durante a construção do sentido, e é justamente pela recorrência de elementos lingüísticos que resolvemos adotar a repetição como boa formadora de textos. Partindo do pressuposto de que a repetição é característica de todo texto (de acordo com a especificidade de cada tipo textual) quando se deseja persuadir, retomar conceitos, enfatizar ou até mesmo somente informar, em se tratando do texto especializado, ela dá ao leitor a possibilidade de recriar e reorganizar a situação vigente no universo textual, transformandoo em um texto com características da objetividade. O processo que descreve o objeto tenta uma maior proximidade com o real, a fim de alcançar o objetivo a que se propõe. 
Para que a compreensão da leitura se dê de maneira eficaz, o reconhecimento das partes que constituem um texto especializado é fundamental. De acordo com Bevilacqua, (apud KRIEGER; FINATTO, 2004, p. 190), esse tipo de texto envolve o público-alvo, ao perceber para que serve o que se vai afirmar, o nível de abstração envolvido, o seu grau de precisão; envolve, também, a identificação do uso de linguagem artificial ou de outros códigos como tabelas, gráficos, e ainda se há inserção de linguagem especializada ao longo do texto. Caso não se verifiquem essas postulações de recepção do texto especializado, o risco de má formação textual é grande, e, por isso, o leitor não pode ser responsabilizado por não conseguir dar conta dos elementos que constituem a coerência, uma vez que a colaboração para que o texto seja compreendido também é do produtor, o qual deve atender às questões que envolvem o recebimento desse tipo textual.

Em relação à macroestrutura do texto especializado, segundo Krieger e Finatto (2004, p. 191),

\begin{abstract}
deve-se procurar reconhecer a totalidade do texto em relação às suas partes constitutivas mais gerais, tais como suas subdivisões, temas, paragrafação, títulos. São observados também características e objetivos dos sujeitos enunciador e destinatário, particularizando-se o tipo de texto em questão e a situação comunicativa.
\end{abstract}

De acordo com as autoras, a macroestrutura revela marcas específicas de um tipo de texto e de uma linguagem especializada. Ao se deparar com essas marcas, o leitor consegue perceber os objetivos e as intenções por parte do produtor, mesmo quando a compreensão da leitura é dificultada devido a outros fatores lingüísticos presentes. Ao produtor e leitor, mesmo não sintonizados durante a situação de comunicação, a partir das características observadas no texto, será possível a construção do sentido.

Em se tratando da instalação e funcionamento de um produto eletrônico, não há necessidade de um texto introdutório, e menos ainda de conectores argumentativos para ligar uma idéia à outra (isso se observa em nossa análise), para desenvolver ou defender pontos de vistas. Dessa maneira, a descrição de todo e qualquer processo descritivo, de acordo com Garcia (200, p. 398), se caracteriza por:

a) exposição em ordem cronológica; b) objetividade, sem linguagem rebuscada, abstrata ou afetiva; c) ênfase na ação, que deve ser suficiente detalhada; d) indicação clara das diferentes frases do processo; e) ausência de suspense, ou seja, o interesse da descrição de processo não deve depender da expectativa ou do suspense.

A descrição de um processo vem acompanhada de gravuras e ilustrações, esclarecendo e informando o leitor de como se deve proceder durante a tarefa de instalar um aparelho eletrônico. Como vimos, as características apontadas por Garcia nos revelam um mundo estático, parado, contendo informações concisas e apuradas, através de apresentações detalhadas de partes bem definidas; verifica-se também, de acordo com o manual de instruções analisado, uma linguagem de fácil entendimento.

Quando o propósito é mostrar o funcionamento de um aparelho eletrônico bem como os estágios de um processamento, o especialista em terminologia, conforme Faulstich 
(1995, apud GALVÃO, 2004), deve, entre outras posturas, medir as condições de produção e de recepção do texto técnico. Deve, ainda, pensar a que tipo de leitor se direciona o texto, com que intenção ou finalidade ele é escrito, em que situação de fala e escrita e por quem foi produzido. Acreditamos que, ao produzir um texto, o autor mostre a que veio, ou seja, se faça entender e tenha a intenção de contribuir para o esclarecimento das informações contidas no mesmo. Se o objetivo, em um manual de instruções, é ler e seguir cada etapa da instalação do aparelho eletrônico até fazê-lo funcionar, a descrição necessita ser precisa e ter linguagem acessível a qualquer tipo de leitor.

\section{O MANUAL DE INSTRUÇÕES DE DVD}

Iniciando nosso estudo acerca do instrumento e métodos utilizados, será trabalhado apenas um corpus: duas páginas do manual de instruções de um DVD (PHILIPS, 2000). É importante destacar que são páginas em seqüência, não é possível desmembrá-las para a construção do sentido do texto, pois a partir delas o procedimento de instalação do aparelho eletrônico tem início. Optamos por selecionar essas partes porque relacionam texto e ilustração, que dizem respeito à parte da conexão por meio de cabos, que ligam a TV ao DVD. Dessa forma, acreditamos ser mais interessante nos determos no aspecto da repetição, a qual nos dá indícios de coerência global no texto.

Em se tratando de um artigo, não temos espaço para que analisem e se discutam os vários aspectos detectores de coerência textual, o que talvez nos levasse a um resultado mais amplo do estudo realizado. Sendo assim, por meio do indício de compreensão de leitura, procuramos entender como o sentido de um texto especializado é organizado e de que forma ele chega até o seu receptor, isso mediante a recuperação da coerência. Esclarecemos que não estamos falando de estudos quantitativos, tampouco de conteúdos extensos.

O manual de instruções em questão, por se tratar de um conteúdo relativamente extenso, dificulta uma apreciação detalhada dos elementos que envolvem a coerência textual, que são muitos. Ao delimitar o aspecto a ser estudado, acreditamos que a escolha da meta-regra de repetição nos ajuda a recuperar a coerência do texto. Queremos registrar aqui idéias relevantes e que realmente nos tragam reflexões importantes, contribuindo, assim, para os estudos do texto especializado.

\section{A RECUPERAÇÃO DA COERÊNCIA NO TEXTO ESPECIALIZADO}

Nas Figuras 1 e 2 selecionadas do manual de instruções, é possível destacar alguns aspectos interessantes quanto à estrutura e à organização dentro do texto. Comecemos por verificar que as seis etapas da conexão que liga, através dos cabos, o DVD à TV, não são numeradas conforme a seqüência de passos, dificultando a ordem do processamento, pois não sabemos se podemos seguir apenas uma delas para a instalação ou todas. Entretanto, há numeração entre as partes de cada etapa (texto e ilustração), o que mostra uma seqüência de ações. Só vamos poder perceber que se trata de uma seqüência de imagens, a partir da quarta imagem, que apresenta o seguinte enunciado: "depois de conectar tudo corretamente, 
conecte o cabo de alimentação na tomada elétrica. Na primeira cena do processamento das etapas da página 6, lemos: é necessário fazer apenas uma das conexões de vídeo sugeridas abaixo" (PHILIPS, 2000, p. 6). A opção das duas conexões não está nessa página, e sim, na seguinte, fazendo o leitor parar a leitura para observar a página que segue.

O manual de instruções, no nosso caso, de modo geral, não apresenta seqüência de texto (texto único), o que torna a repetição a principal característica textual, com a função de juntar as idéias, dar continuidade ao propósito. São pequenos fragmentos de textos que ordenam (use, selecione, nunca faça, altere) ao leitor cumprir as tarefas indicadas. Assim, o que realmente recupera a coerência do texto é a relação que se estabelece entre o próprio texto e a imagem, via repetição ( $o$ cabo - na apresentação do texto - o cabo - na representação da imagem). Essa relação, porém, torna-se difícil quando os nomes das partes (os termos técnicos), tanto da TV quanto do aparelho eletrônico, nas duas primeiras imagens, são escritas ilegíveis, minúsculas palavras. Ainda, só é possível a conexão dos cabos à $\mathrm{TV}$, por meio dos números 1 e 2 da primeira etapa e 1, 2 e 3 da segunda etapa, os quais são apresentados, primeiro, textualmente, e logo depois, representados nas imagens. Desta ordem de processamento das instruções de cada etapa, podemos afirmar que os fragmentos de textos se completam, o que significa dizer que não podemos separá-los enquanto parte integrante, cada um, do processo de instalação do aparato eletrônico e como forma de construir o sentido do todo do texto.

Imaginemos a situação de não haver ilustrações, apenas os fragmentos textuais nos guiando no processo de instalação do DVD, talvez não conseguíssemos, mesmo um fragmento dando seqüência ao outro, construir o sentido porque nos faltaria estabelecer a relação do texto com a imagem. Se invertêssemos a situação, se somente tivéssemos a imagem como guia de instalação do aparelho eletrônico, a construção do sentido, talvez, seria mais profícua, devido à imagem contemplar a figura tanto do material a ser utilizado como do próprio aparelho eletrônico.

Diante disso, o que se percebe é que, neste estudo, através da repetição dos termos técnicos ao longo dos pequenos fragmentos de texto, consegue-se dar continuidade e também dar sentido ao ritual de instalação do aparato eletrônico. Porém, é preciso não esquecer que, também, o conhecimento (definição) de determinados termos técnicos pelo leitor ajudam muito para que a compreensão da leitura aconteça, bem como o conhecimento do léxico e a familiarização com o próprio manual de instruções e com outros já manuseados. Um exemplo dessa repetência: as palavras DVD player. Primeiro, devemos reconhecer que por se tratar de um aparelho de DVD, não seria incomum encontrarmos essas palavras muitas vezes ao longo do texto, no entanto a repetição da expressão nos chama atenção: as palavras marcam a coerência no texto, elas precisam ser (re)apresentadas ao leitor a todo o momento, pois é uma forma de mantê-lo atento às instruções das partes do aparelho eletrônico; também, essas palavras servem de referência para o leitor, que, imediatamente, estabelece a relação que existe entre $D V D$ player e todo o resto que se refira a ele.

Em todos os segmentos (textos) de cada etapa do processamento, DVD player se repete, o que seria uma tendência, já que estamos falando de um aparelho de DVD. Relacionando a primeira imagem com as instruções ( 1 e 2), o enunciado é "Uso da tomada composite vídeo (CVBS): 1) use o cabo (...) para conectar a tomada CVBS do DVD player. 2) para ouvir os canais de áudio do DVD player..." (PHILIPS, 2000, p. 6). Essa situação de 
repetição acontece também na relação das imagens subseqüentes com seus respectivos passos. Podemos, então, observar que, nesse caso especificamente, a repetição faz com que o leitor, através da remissão a termos, consiga construir o sentido do texto através da relação que estabelece entre o texto e a imagem. Na verdade, acreditamos que seja uma estratégia do produtor redizer, e com isso o leitor ler várias vezes as mesmas palavras. Nota-se que, além dos verbos no imperativo, as palavras repetidas são aquelas que obrigatoriamente devem ser reconhecidas por quem está lendo, para a instalação do aparelho de DVD (cabo coaxial, tomada CVBS, cabos component vídeos). Dessa maneira não são meros vocábulos descritos, são traços de coerência fortemente marcados pelo produtor e percebidos pelo leitor que está se empenhando em reconhecer o texto como coerente.

Tudo o que se lê em um manual de instruções, as finalidades, etapas e os termos específicos dos materiais utilizados, tem relação direta com a instalação do aparelho de DVD, sendo assim, o leitor começa a entender o que está lendo, pois percebe que tipos de instruções são apresentados, que finalidades se verificam aí e começa a seguir as etapas propostas. Uma outra observação importante diz respeito aos cabos de conexão que acompanham o aparelho eletrônico. Cada um deles é de uma cor, com isso, facilita-se o processo para a conexão do DVD à TV. Vejamos os exemplos: "Use os cabos Component Vídeo (vermelho/azul/verde) para conectar as tomadas Y Pb Pr ou Para ouvir os canais de áudio do DVD player pelo modulador de RF, use os cabos de áudio (branco/vermelho)" (PHILIPS, 2000, p. 7), imagens 3 e 4, respectivamente. Dito isso, o leitor somente conseguirá seguir adequadamente as instruções se tiver em mãos os cabos de cores.

Havendo uma possível dificuldade de compreensão de leitura bem como das etapas descritas, por meio dos diferentes termos técnicos usados no texto, a aceitação do manual de instruções pode não se dar num primeiro contato, numa primeira leitura, por isso o leitor deve ser persistente. Ele sabe que se não tem a mínima noção de eletrônica e de como se instala um aparelho de DVD, sendo assim, precisará da ajuda desse guia de funcionamento. Nesse sentido, ele, o leitor, coopera ao máximo para o entendimento do texto. Em se tratando de cooperação, Charolles (1988, p. 53) afirma que o leitor contribui no sentido de compreender o texto, mesmo parecendo-lhe totalmente incoerente. Ser leitor é na verdade fingir que está compreendendo o que está lendo num primeiro momento, logo ou continua fingindo ou então colabora para que o texto se torne coerente, interpretável.

A recuperação da coerência, em um manual de instruções, nem sempre é alcançada pelo leitor que se vê diante de um texto que instrui a fazer algo. Concordemos que a descrição de um processo de instalação e funcionamento de um aparelho de DVD é diferente da de uma descrição física ou psicológica de uma pessoa, por exemplo. Primeiro porque os objetivos de ambas são diferentes, a descrição física ou psicológica requer sensibilidade de quem está ou observando ou escrevendo o texto em relação às ações e comportamentos, já a descrição de processamento requer a instrução de passos e etapas que resultem no funcionamento de um tipo de aparelho eletrônico. Diante dessa especificidade que o texto especializado tem, é que a recuperação da coerência do manual de instruções estudado se instaura a partir da relação texto/imagem. Esquematizando, equivale à seguinte ordem de construção de sentido: 
TEXTO
\[ \text { apresentação dos termos técnicos } \]

\author{
IMAGEM \\ L representação dos termos técnicos
}

Por meio deste esquema, é possível observar que, para recuperar a totalidade do texto, ou seja, recuperar a coerência, é preciso estabelecer a relação texto/imagem. Significa dizer que, automaticamente, passamos a relacionar os cabos e tomadas descritas no texto, com as suas representações na imagem. Assim, se o texto diz conectar à TV o cabo amarelo, na imagem estará lá o cabo amarelo conectado no lugar certo. Um outro exemplo dessa relação está na terceira imagem, são três passos para conectar o modulador RF à TV. $O$ passo 3 diz: "Use o cabo coaxial de RF para conectar o modulador de RF na tomada RF do TV (cabo não fornecido)" (PHILIPS, 2000, p. 6). O cabo coaxial será reconhecido, já que não acompanha o aparelho de DVD, somente quando o leitor fizer a relação do texto com a imagem e verificar que há um cabo (na imagem) e que esse tem o nome de cabo coaxial. O mesmo acontece com o modulador, pois ele não é fornecido juntamente com o aparelho, assim, somente a partir da imagem o leitor vai tentar compreender o que se está instruindo.

Supõe-se, então, que a repetição de termos técnicos, seja dentro do próprio texto apenas ou na relação que se estabelece entre $o$ texto $e$ a imagem (apresentação/representação), pressupõe que a assimilação do sentido vai acontecer gradualmente. O leitor, aos poucos, começa a captar essa repetição como forma de construção do sentido, o que nos leva a afirmar que os termos técnicos, além de dar nome aos materiais usados no processo da instalação, auxiliam na recuperação da coerência do texto.

É de muita importância observar que conectar o aparelho eletrônico à TV é apenas o primeiro passo para fazê-lo funcionar, passo esse que dá inicio ao processo de instalação, que atesta o sucesso da operação realizada, porém não concluída, pois é preciso outro desafio: saber eleger as opções de menu do controle remoto, por exemplo.

\section{CONSIDERAÇÕES FINAIS}

Neste estudo piloto, foi verificado que, em um texto especializado, como é o caso do manual de instruções, a descrição, os objetivos e as intenções estão centrados na perspectiva de conseguir compreender o texto em sua totalidade para que se instale um aparelho de DVD e o faça funcionar. Nesse sentido, o texto especializado tem suas limitações, como qualquer outro tipo de texto. $\mathrm{O}$ que se verifica é que, independentemente do tipo textual que se apresente, todos têm como características os propósitos que norteiam a situação de comunicação vigente, os mundos envolvidos e a finalidade desejada.

Percebe-se, dessa forma, que quando se produz um manual de instruções, questões de recepção, tais como: para quem se produz, com que finalidade e qual a estratégia mais adequada para que o leitor reconheça esse texto como sendo coerente, são necessárias e precisam ser respondidas, pelo produtor do texto, antes de levar esse tipo de material a quem irá recebê-lo. Como conseqüência disso, a compreensão de leitura desse texto torna- 
se difícil, principalmente devido aos termos técnicos empregados, como pudemos observar na análise realizada. Por isso, a recuperação da coerência, nesse caso, se dará pela relação texto/imagem, via repetição. Isso mostra que os manuais de instruções devem ser mais bem elaborados, com o objetivo de dar mais importância a essa relação estabelecida, não deixando de relacionar o que vem antes com o que virá depois. Se a chave da construção do sentido tem como peça fundamental a imagem, na relação com o texto, ela deve ser nítida e transparente, as ilustrações bem desenhadas, bem como as partes dos aparelhos (DVD e TV) escritas legivelmente, que possam ser entendidas por quem as lê.

Contudo, após discutirmos os resultados obtidos sobre o estudo da compreensão de leitura de um tipo de texto que descreve passos com o objetivo de instalar um aparelho eletrônico, observamos que há muito que pesquisar ainda no campo do texto especializado. Escrevemos sobre a relação texto/imagem em um manual de instruções. Entretanto, é preciso, futuramente, estudar a produção desse tipo de texto: quem o elabora; com que objetivos; que tipo(s) de leitor(es) se quer atingir. Além disso, realizar pesquisas que incluam técnicos da eletrônica e o próprio produtor do texto como sujeitos. Fatores dessa natureza certamente iriam colaborar para o entendimento e compreensão do texto especializado, hoje em dia, lido por vários tipos de leitores, todos, com propósitos bem parecidos: o de serem informados, o de serem instruídos na tarefa de fazer funcionar esse aparato eletrônico e, acima de tudo, o de serem descritas etapas do processamento de instalação de um aparelho de DVD.

Enfim, investigamos, neste trabalho, como o leitor recupera a coerência em um manual de instruções, texto que, por se tratar de um gênero textual descritivo, tem características peculiares que o tornam objetivo e direcionado ao leitor que pretende instalar e fazer funcionar um aparelho de DVD. E é dessa maneira, pela relação que o leitor tenta estabelecer entre palavras e imagens, que acreditamos ser possível a compreensão do texto especializado e, principalmente, do manual de instruções, um gênero de texto instrucional.

\section{REFERÊNCIAS}

CHAROLLES, M. Introdução aos problemas da coerência dos textos. In: GALVEZ, C. H; ORLANDI, E; OTONI, P. (org.) O texto: leitura e escrita. Campinas: Pontes, 1988, p. 3585.

GALVÃO, Maria C. B. A linguagem de especialidade e o texto técnico-científico: notas conceituais. In: Transenformação, 16 (3), p. 241-251, set./dez, 2004.

GARCIA, Othon M. Comunicação em prosa moderna: aprenda a escrever, aprendendo a pensar. $22^{\mathrm{a}}$ ed. Rio de Janeiro: Editora FGV, 2002.

KLEIMAN, A. Texto e leitor: aspectos cognitivos da leitura. Campinas, São Paulo: Pontes, 1989.

KOCH, I.V. O texto e a construção de sentido. São Paulo: Contexto, 1997.

KOCH, I. V \& TRAVAGLIA, L. C. Texto e coerência. São Paulo: Cortez, 1989.

KRIEGER, M. G. \& FINATTO, M. J. Introdução à terminologia: teoria e prática. São

Paulo: Contexto, 2004.

PHILIPS. Manual de instruções. DVD Vídeo Player, 2000, p. 6-7. 


\section{ANEXOS}

\section{LUREXOES}

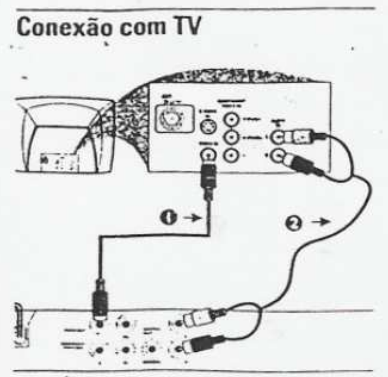

IMPORTANTE!

Dependendo dos recursos do seu TV. é necessário fazer apenas uma das conexōes de video sugeridas abaixo.

- Conecte o DVD player direto no TV.

Uso da tomada Composite Video (CVBS)

1 Use o cabo Composite Video (amarelo) para conectar a tomada CVBS IVIDEO OUT) do DVD player na tomada de entrada de video do TV (que pode estar identificada como AN In, Video In. Composite ou Baseband) (cabo fornecido)

2 Para ouvir os canais de áudio do DVD player pela TV, use os cabos de áudio (branco/vermelho) para conectar as tomadas AUDIO OUT (L/R) do DVD player às entradas de áudio (AUDIO IN) do TV (cabo fornecido).

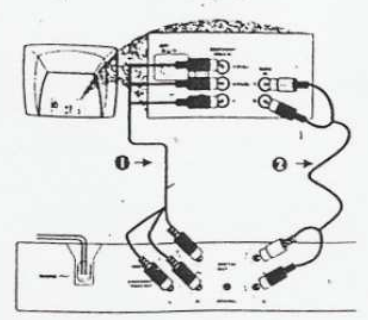

IMPORTANTE!

A qualidade de video Progressive Scan só é possivel quando se usa $Y$ Pb Pr. É necessária um TV com Progressive Scan.

Uso da tomada Component Video (Y Pb Pr)

1 Use os cabos Component Video

Ivermelho/azul/verde) para conectar as tomadas Y Pb Pr do DVD player nas tomadas de entrada Component Video do TV (que podem esiar identificadas como $\mathrm{PrCr} / \mathrm{PbCb} / \mathrm{Y}$ ou YUV) (cabo nâo fornecidol.

2 Para ouvir os canais de áudio do DVD player pela TV, use os cabos de áudio (branco/vermelho) para conectar as tomadas AUDIO OUT (L/R) do DVD playe às entradas de áudio (AUDIO IN) do TV (cabo forñecido).

3 Vá para a página 11 para obter informaçōes detalhadas sobre 0 ałuste do Progressive Scan.

(Fonte: PHILIPS, 2000, p. 6)

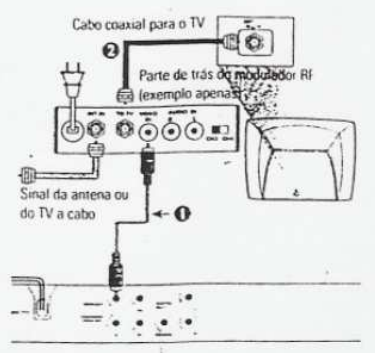

IMPORTANTE!

Se seu TV tiver apenas uma entrada Añteñiâa in ( 75 ofim ou fif in), você vai precisar de um modulador de RF para visualização da imagem. Consulte seu revendedor ou a Philips sobre a disponibilidade e funcionamento do modulador de RF.

Como usar um modulador de RF

1 Use o cabo Video Composto (amarelo para conectar a tomada CVBS IVIDEO OUT) do DVD player com a tomada Video In do modulador de RF.

2 Para ouvir os canais de áudio do DVD player pelo modulador de RF, use os cabos de áudio (branco/vermeltio) para conectar as tomadas AUDIO OUT (L/R) do DVD player às entradas de áudio (AUDIC IN) do modulador de RF (cabo fornecido)

3 Use o cabo coaxial de RF para conectar o modulador de RF na tomada PF do TV (cabo nāo fornecido)
Conexão do cabo de alimentaçã

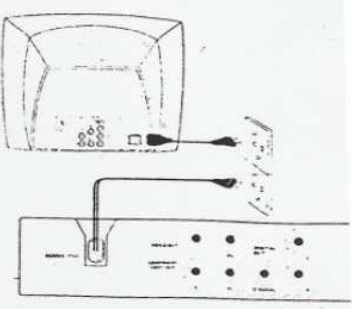

Depois de conectar tudo corretamente conecte o cabo de alimentação na tomada da rede elétrica (CA). Nunca faça ou altere conexōes : $2 m$ o aparelho ligado

Quando não houver um disco na gaveta, pressione STANDBY ON no painel frontal do DVD player, "... aparecer no display.

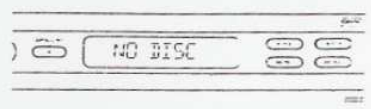

Figura 1 - Página 6 do Manual de Instruções do DVD analisado 


\section{CONEXÕES}

\section{Opcional : Conexão de aparelho estéreo de 2 canais}

(Fonte: PHILIPS, 2000, p. 7)

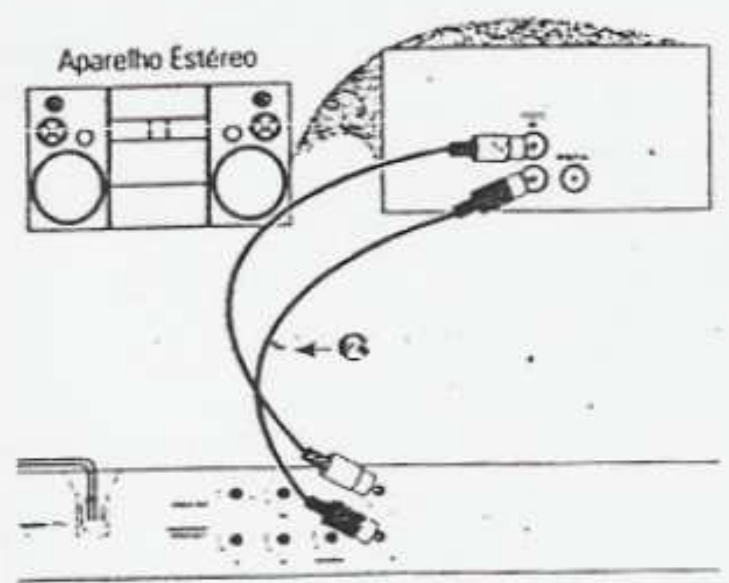

O apareiho estéreo tem tomada Dolby

Pro Logic ou entradas de áudio esquerda e direita (Audio in Left/Right).

1 Selecione uma das conexões de video ICVBS VIDEO IN, COMPONENT VIDEO

(N): dependendo das opçōes disponiveis em seu TV.

2 Use os cabos de audio (branco/vermelho) para conectar as tomadas AUDIO OUT (L/ R) do DVD player nas respectivas tomadas AUDIO IN do aparelho estéreo (cabo fornecido).

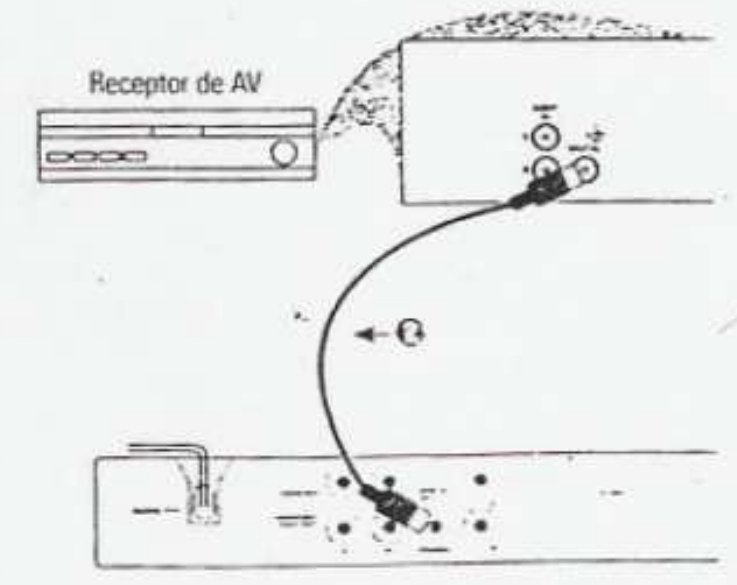

Ô recepior tem um decodificador PCivi, Dolby Digital ou MPEG2

1 Selecione uma das conexōes de video (CVBS VIDEO IN, COMPONENT VIDEO IN). dependendo das opções disponiveis em seu TV.

2 Conecte a tomada COAXIAL do DVD player na respectiva tomada Digital Audio in (COAXIAL) do receptor (cabo nâo fornecido).

3 Dependendo dos recursos de seu receptor, selecione Só PCM ou Todas na opçāo Saida Digital do DVD player Iveja "Configuraçào de áucio digital" na página 22!

Sugestão Utit:

- Se o formato de áudic da saida digital nào corresponder aos recursos de seu receptor, o receptor enitirà um som forte e distorcido, ou mesm rienhum som

Figura 2 - Página 7 do Manual de Instruções do DVD analisado 